\title{
Celebrate Darwin Day, An Event for Education and Outreach in Evolutionary Biology
}

\author{
Rachel M. Goodman
}

Published online: 10 June 2008

C) Springer Science + Business Media, LLC 2008

\begin{abstract}
Darwin Day is an international celebration of Charles Darwin's birthday, February 12, and is used as an occasion for education and outreach in evolutionary biology. I describe the history and structure of Darwin Day at the University of Tennessee, one of the oldest Darwin Day organizations in the world. I detail past events including speakers, themes, and advertising ideas that have worked for us and suggestions for getting a Darwin Day started. I encourage interested groups especially those at schools, museums, libraries, nature centers, and other institutions to adapt ideas from our organization to fit their own circumstances and to start planning their own Darwin Days for the celebration of Darwin's 200th birthday in 2009.
\end{abstract}

Keywords Charles Darwin · Evolutionary biology .

History · Community · Intelligent design · Tennessee

Every year, groups of volunteers around the world celebrate evolutionary biology on the occasion of Charles Darwin's birthday, February 12. These events are collectively referred to as "Darwin Day." The goals of Darwin Day are to reach out and inform the public about the importance of evolution as the foundation of modern biology, the life and findings of Charles Darwin, and to promote scientific literacy in general. Darwin Day is especially important in the United States today because the percentage of citizens who accept the evidence for evolution is among the lowest of industrialized nations (Miller et al. 2006). Many

R. M. Goodman ( $\bowtie)$

Department of Ecology and Evolutionary Biology,

University of Tennessee,

569 Dabney Hall, 1416 Circle Drive,

Knoxville, TN 37996-1610, USA

e-mail: rmgoodman@utk.edu
Americans mistakenly believe that there is a legitimate controversy among scientists regarding the general acceptance and status of evolutionary biology, a belief recently fueled by the "teach the controversy" strategy among antievolutionists including the leading organization, the Discovery Institute (http://www.discovery.org/ accessed Apr 2008; DeWolf et al. 1999; Matzke and Gross 2006). As scientists and educators, we are responsible for countering this misinformation and communicating the importance of evolutionary biology for many areas of public benefit, such as agriculture, medicine, and industry.

Darwin Day at the University of Tennessee, Knoxville (UTK) serves the east Tennessee community. Our organization is open to all community members, though primarily composed of UTK students and faculty. Annual events draw in several hundred people from the university and surrounding community, and these events are especially important and relevant to east Tennessee. The famous "Scopes Monkey Trial" of 1925 took place in nearby Dayton, TN, USA, and laws prohibiting the teaching of evolution remained on the state books for four decades thereafter. In 2005, textbook stickers with antievolution disclaimers were proposed in one county school board (Slevin 2005), and another county school board passed a resolution encouraging teachers to present intelligent design alongside evolutionary biology (Blount County Board of Education 2005). In the same year, then Senator Bill Frist of Tennessee said that intelligent design should be taught in public schools alongside evolution (Stout 2005). We of Darwin Day at UTK try to counteract the misunderstanding, ignorance, and/or distrust of evolutionary biology among many in our community by providing the occasion for a noncombative and rational discussion of the field while remaining sensitive to the diversity of cultural and religious perspectives we encounter. 


\section{History of Darwin Day at UTK}

Since Darwin's death in 1882, there have been many organized celebrations of his contributions to evolution, including a celebration of his 100th birthday by the New York Academy of Sciences in 1909 and "Phylum Feasts," wherein food items encompass all living phyla, beginning in the 1970s (Anon 1909; Schueler accessed Jan 2008). A week-long "Darwin Festival" has been ongoing at Salem State College in Massachusetts since 1980 (Darwin Festival accessed Jan 2008), and the Stanford Humanists student group and Humanist Community began a series of events in 1995 which continued on to become a Darwin Day celebration (The Humanist Community; http://www. darwinday.org/englishL/home/2007.php; accessed Jan 2008). The first Darwin Day at UTK was organized independently of the other events in 1997 by Dr. Massimo Pigliucci, then Assistant Professor in the Department of Ecology and Evolutionary Biology (EEB). When he moved on to Stony Brook University in 2004, the event came to be organized mostly by graduate students and continues to be regularly housed under EEB.

In 1997, the first Darwin Day consisted of an information booth, a film series at the UTK library, a book display in the campus bookstore, initiation of the organization's webpage, and a keynote address by Dr. Douglas Futuyma on "Evolution, Science, and Society." Since that time, our events have grown to include multiple speakers, panel discussions on issues, radio interviews, essay contests, distribution of merchandise and informational materials promoting evolution, and workshops for local area teachers. Darwin Day and related events have sprung up all over the world, and in 2007, the International Darwin Day Celebration website listed over 800 such events (http://www.darwinday. org/englishL/home/2007.php, accessed Jan 2008). These took place on every continent except Antarctica, though the vast majority occurred in the United States (725 events). The Discovery Institute has responded to the growing popularity of Darwin Day by sponsoring and advertising counter-events on the official Darwin Day Celebration website (seemingly to confuse potential attendees) as well as their own website, http://www.discovery.org (accessed Apr 2008). Also, their criticisms of Darwin Day and evolutionary biology have been publicized with the recent book Darwin Day In America: How Our Politics and Culture Have Been Dehumanized in the Name of Science by John West, a senior fellow at the Discovery Institute (West 2007).

Each year, our Darwin Day group plans our main events for several days on or around February 12, according to the UTK academic schedule. Recently, we have had a different theme each year, with speakers and movies that correspond to the theme (Table 1). The message and membership of the group in its early years were perceived as antagonistic to some Christian faiths. Unfortunately, Darwin Day events in general may be perceived as such, regardless of their content or sponsorship. In recent years, we have moved increasingly towards a noncombative approach that is sensitive to diverse groups, culminating in the theme of "Science and Religion" in 2006. Events included presentations by Rev. Michael Dowd on campus and at churches of the United Church of Christ and the Unitarian Universalist Church, and a teachers' workshop at a the Unitarian Church. We discussed the diversity of religious denominations that do not find any conflict with evolution and stressed that science is not meant to interfere with or dictate religious beliefs. Our group has also changed our name from the original "Tennessee Darwin Coalition" to a more neutralsounding "Darwin Day at the University of Tennessee," and recently, we have stopped displaying older merchandise containing the Darwin fish with legs (humorous to many but an unnecessary co-opting of a religious symbol). Importantly, the board of directors reminds participants and volunteers before all events to respect diverse opinions, to present only the science and not their personal religious beliefs, and to remain calm and polite in all discussions. Negative and aggressive responses from the community have toned down over the years, which we believe is in response to our noncombative approaches. Our speakers still receive challenging questions and students express opposing opinions in follow-up essays for classes, but the general tone is one of respectful and open discussion.

Although we are consistently housed, funded, and logistically supported through the EEB department at UTK, we receive wonderful support from many other departments, programs, and offices in the university (see Acknowledgements). While merchandise sales bring in some money, we primarily-fund raise at the university through letters from our faculty representative and current student president. We have no fees for membership, distribute information through a free list serve, maintain free and inclusive public events, and have charged either nothing or a small fee to cover materials for our teacher workshops.

\section{Typical Events during Darwin Day at UTK}

Keynote and Academic Lectures Our guest speaker always gives a keynote lecture intended for a general public audience and often also gives a more technical seminar on a similar theme during the daytime for the academic oncampus audience. In some years, we have had multiple guest speakers over a period of days (more recently) or weeks. After the lecture and Q \& A session, we move to a casual café or bar where audience members can carry on extended discussion with the speaker. 
Table 1 Themes for Darwin Day events at the University of Tennessee, Knoxville, with corresponding guest speakers and titles of talks

\begin{tabular}{|c|c|c|}
\hline Year & Guest speakers & Theme/titles of talks \\
\hline 2008 & Eugenie Scott, Ph.D. & Intelligent design: is it science? Should it be taught in schools? \\
\hline 2007 & $\begin{array}{l}\text { Randolph Nesse, M.D. } \\
\text { Paul Ewald, Ph.D. }\end{array}$ & Evolution and medicine \\
\hline 2006 & $\begin{array}{l}\text { Rev. Michael Dowd } \\
\text { Tim Berra, Ph.D. }\end{array}$ & $\begin{array}{l}\text { Evolution and religion } \\
\text { Darwin's biography }\end{array}$ \\
\hline 2005 & Michael Shermer, Ph.D. & $\begin{array}{l}\text { Science of good and evil: evolutionary origins of morality } \\
\text { Why people believe weird things: creationism, holocaust denial, and beyond }\end{array}$ \\
\hline 2004 & Stephen Palumbi, Ph.D. & Rapid evolution in modern life \\
\hline 2003 & Ian Tattersall, Ph.D & Hominid evolution \\
\hline 2002 & Elliot Sober, Ph.D. & $\begin{array}{l}\text { The design argument } \\
\text { Common ancestry and natural selection }\end{array}$ \\
\hline 2001 & Barry Palevitz, Ph.D. & $\begin{array}{l}\text { Never say uncle: creationism and intelligent design } \\
\text { Talks and activities coordinated with university theater's production } \\
\text { of "Inherit the Wind" }\end{array}$ \\
\hline \multirow[t]{4}{*}{ 2000. (Spread over 3 months) } & Donald Prothero, Ph.D. & $\begin{array}{l}\text { Does climate drive evolution? } \\
\text { Evolution? The fossils say Yes! }\end{array}$ \\
\hline & Ken Miller, Ph.D. & $\begin{array}{l}\text { Finding Darwin's God: On the apparent conflict between evolution and religion } \\
\text { Organized teachers' workshop-teaching the fact and theory of evolution } \\
\text { Meshing classroom practice with science and with common sense }\end{array}$ \\
\hline & Frans de Waal, Ph.D. & $\begin{array}{l}\text { The rewards of cooperation: Cognitive aspects of primate reciprocity } \\
\text { Good natured: the evolution of morality in humans and other animals }\end{array}$ \\
\hline & Michael Ruse, Ph.D. & $\begin{array}{l}\text { Evolutionary ethics: a phoenix arisen? } \\
\text { Darwinism and atheism: a marriage made in heaven? }\end{array}$ \\
\hline 1999 & Rev. Barry Lynn & Separation of God and Darwin \\
\hline 1998 & $\begin{array}{l}\text { William Provine, Ph.D. } \\
\text { Eugenie Scott, Ph.D. }\end{array}$ & $\begin{array}{l}\text { Evolution: free will and punishment and meaning in life } \\
\text { Organized teacher workshop- Teaching evolution: resolving the controversies }\end{array}$ \\
\hline 1997 & Douglas Futuyma, Ph.D. & Evolution, Science, and Society \\
\hline
\end{tabular}

Teachers' Workshop The teachers' workshop, mainly targeted at local high school and middle school teachers, may be our most important outreach to the community. The format has varied over the years. Recently, we have offered an evening workshop which provides ideas and resources for teaching evolution and also serves as a support group for local teachers who are often challenged by students, parents, and colleagues within their schools when they teach evolution. Recently, an off-campus location has been used and a minimal registration fee required. We work with the local science teachers and administration to be sure that appropriate paperwork is filled out so teachers can receive in-service credit. Each year, the presentation material is different, and we have provided materials which can be used or converted for classroom use. In 2008, we put together a large packet of handouts (some available at our website, http://eeb.bio.utk.edu/darwin), a list of helpful websites, and both science education journal and popular articles on evolution education to distribute. We also distributed copies of the National Academies' newest resource on evolution, "Science, Evolution, and Creationism" (available for free download as a PDF at http://www. nap.edu/sec). Materials were kindly provided free of charge by the National Center for Science Education (NCSE), and many of these are available on their website, http://www. ncseweb.org/. The list of websites that we compiled in 2008 is included in Table 2 and available as live links on our Darwin Day at UTK website.

Information booth In our University Center, we set up an information booth with advertising for our events, Darwin Day merchandise for sale, free informational handouts, and two volunteers to answer questions. We do this the day before and on the first day of the other events, to increase campus awareness of our goals and activities. Our informational handouts are available for download on our website, and others are available online from the American Association for the Advancement of Science, http:/www. aaas.org/news/press_room/evolution, and online (or paper by request) from NCSE.

Documentaries and discussions We show a series of several recent documentaries about evolutionary biology, the history of the social controversy surrounding the science, the life of Charles Darwin, and so on, followed by short discussions led by volunteers. We get teachers from several biology and anthropology courses offered on campus to give extra credit for students attending these and 
Table 2 Online resources for teaching evolution

Online resources

Resources on Evolution at National Center for Science Education http://www.natcenscied.org/article.asp

"Cans, Can'ts and Shoulds of Teaching Evolution" http://www. ncseweb2.org/multimedia/nsta06/nsta06.html

Understanding evolution: your one-stop source for information on evolution http://evolution.berkeley.edu/

NOVA “Judgment Day: Intelligent Design on Trial” film http://www. pbs.org/wgbh/nova/id/program.html

Evolution and the Nature of Science Institutes (ENSI) http://www. indiana.edu/ ensiweb/

Evolution resources from the National Academies http:// nationalacademies.org/evolution/

Evolution and the Nature of Science Institutes http://www.indiana. edu/ ensiweb/

Darwin Day Celebration (the main international group) http://www. darwinday.org/

EvoWiki http://wiki.cotch.net/index.php/Main_Page

National Evolutionary Synthesis Center (NESCent) Education and Outreach Group http://www.nescent.org/eog/

Talk.Origins http://www.talkorigins.org/

McGill Journal of Education http://mje.mcgill.ca/issue/view/54
Description

Includes articles "Why Teach Evolution?" and "Facing

Challenges to Evolution Education"

A Powerpoint presentation narrated by Eugenie Scott, executive director of NCSE

A storing house of websites and resources for evolution education; "Teaching evolution" section in the site above includes lesson plans for different class levels

Watch the entire documentary film online, and see accompanying resources for teachers

Originally NSF-funded, the ENSI program focuses on teaching teachers about the nature of science and evolution. A site for teachers by other teachers; many classroom-tested exercises

Includes several, free, downloadable reports on science standards and teaching evolution, research papers on evolution, and other resources Contains lessons and materials for teachers on Nature of science, evolution, Origin of life, and more. You can join a LISTSERV for the group, which regularly sends out news and helpful information.

Provides a list of events around the world, extensive educational material, and suggestions on ways to develop Darwin Day celebrations.

All participants are encouraged to register their events on this website.

Evolution Education Wiki is a free, reader-built encyclopedia of evolution, biology, and origins.

Communicates the results of evolutionary biology research to the general public and scientific community and works to improve evolution education.

Vast collection of articles that explore the creationism/evolution controversy from a mainstream scientific perspective. Topics include "Evidence for Evolution," "Human Evolution," "An Index to Creationist Claims," and more.

Free Online Edition of the journal on Evolution (articles available as PDFs).

Evolution Resources from the American Academy for the Advancement Includes some video, PDFs, and recent news events and commentaries. of Science http://www.aaas.org/news/press_room/evolution/

EVOLUTION: Applications in Human Health and Populations (NESCent) http://www.nescent.org/media/nabt2007/index.html

Based on a recent symposium. Contains video clips, articles, powerpoint talks for use in classrooms, and exercises, all related to human health and disease.

Academic guide to evolution news and research.

Evolution Research News http://www.evolutionresearchnews.org/

A series of articles and other resources from one of the leading defenders of evolution education in the United States.

A discussion board with recent articles and news on evolution and education.

Includes Darwin's writings, biography, and many excellent pictures. Includes short videos from the films, and both teacher and student sections with ideas for activities and discussions on evolution.

An endeavor designed to demonstrate that religion and science can be compatible and to elevate the quality of the debate of this issue.

A list compiled and distributed for the 2008 teachers workshop of Darwin Day at the University of Tennessee, Knoxville; all websites are also available as live links at our website, http://eeb.bio.utk.edu/darwin/.

other Darwin Day events, and run the film series during the day when more students are on campus. Recent movies that we have found to be well done and appropriate include the seven-part Nova "Evolution" series (2001), "War on
Science: Intelligent Design in the Classroom" (2006), "Flock of Dodos" (2007), and "Judgment Day: Intelligent Design on Trial" (2008; some available in part or whole online, see Table 2). 
Student Essay Contest In some years, we have held an essay contest for students, with questions about evolutionary biology and the nature of science. In 2008, there were different divisions, questions, and prizes for middle and high school and college students. We have university faculty judge the contest, announce the winners and hand out prizes at the keynote lecture, and post the winning essays on our website.

Other Events In 2007, we screened the film "Flock of Dodos" before it was widely released and held a panel discussion afterward led by UTK faculty. We have also had panel discussions and debates on a variety of topics in the earlier days of our organization. One year, our local National Public Radio station had an hour interview and call-in show with our faculty representative and student president on the life and science of Charles Darwin and our Darwin Day events. We also try to be involved in other events throughout the year which relate to evolutionary biology and use our list serve as a way to inform members of relevant happenings.

Advertising Advertising is one of our most time-consuming efforts. Volunteers put up posters on campus and in community centers. This often has to be done twice, separated by 1 week, because the posters are actively torn down and sometimes defaced. We lobby hard to get exposure in the local media, through repeated press releases to $\mathrm{TV}$, radio, and print media. We use our own and several other university LISTSERVS to send out email announcements. Advertising for the teachers' workshop requires knowledge of and coordination with the local science teachers and administrators and science education faculty on our campus. We have a large boulder on campus that is traditionally graffitied and defended from invaders through the wee hours of the night and early morning. One year, we successfully painted the rock with advertisements for Darwin Day, requiring the heroic sacrifice of a night's sleep for volunteers during our already busy schedule of events. Another successful strategy is recruiting faculty who teach introductory biology, anthropology, and other related courses to advertise for our events. We communicate with professors early in the semester (while they are designing syllabi), so that they remind students about and assign extra credit for attending Darwin Day events. Our newest strategy to increase student involvement is starting groups on Facebook.com and Myspace.com.

\section{Celebrate Darwin Day: Chuck turns 200 in 2009!}

I encourage all readers to begin a Darwin Day group and plan events at their institutions. In 2009, the world will celebrate the 200th anniversary of Charles Darwin's birthday, as well as the 150th anniversary of the publication of On the Origin of Species. Faculty and students in colleges and universities can recruit similar resources and hold events similar to those described above. We of Darwin Day at UTK are happy to provide handout materials and organizational timelines to anyone starting a Darwin Day. Each year support should grow, and more people and funding resources can be recruited. The organization and local coordination for the teachers' workshop may be the most challenging to initiate, but reaching teachers is of utmost importance. There is increasing agreement that evolution needs to be presented and discussed even before students reach high school (Fail 2006).

Middle and high school teachers and those at other institutions such as museums, libraries, and nature centers can easily modify the above events to fit the time and resources available to them. Museums may present special exhibitions, screen documentaries, and hold lectures. Libraries may showcase a display of books relating to evolutionary biology and Darwin's life. Information displays and bulletin boards can be created by teachers and educators at many institutions. Art, poetry, Darwin impersonations, and essays can be displayed and/or entered in contests. Some have chosen to treat Darwin Day like an actual birthday party, celebrating the event with a birthday cake in class or a barbecue or party. Concerts and bagel brunch discussion groups have been put on for Darwin Day-your imagination is the limit! Examples and ideas for alternative events can be found on the international Darwin Day Celebration website, www.darwinday.org.

A related phenomenon that popped up all over the United States starting in 2006 was "Evolution Sunday," occurring near February 12 at hundreds of churches (also listed on the website above). These church services and activities were meant to demonstrate that evolution and religious faith are compatible. Participating clergy and many members were among those who signed "The Clergy Letter" stating that the majority of Christians find that science and religion are "two very different, but complementary, forms of truth." To learn more about this letter and about organizing an "Evolution Sunday" in conjunction with Darwin Day, visit http://www.uwosh.edu/colleges/ cols/rel_evol_sun.htm (The Clergy Letter Project accessed Jan 2008).

Darwin Day presents a great opportunity to celebrate science and evolutionary biology and introduce the life and scientific contributions of Darwin to people who may not have exposure to these scientifically and historically important issues. I wish you all great success and offer a hand of support for spreading Darwin Day events across the globe to celebrate Chuck's 200th birthday in 2009 ! 
Acknowledgements Many thanks are owed to the Department of Ecology and Evolutionary Biology at UTK which has provided funding, space, and support for Darwin Day since its inception in 1997. Darwin Day at UTK would not be possible without the help of our many volunteers and funding agencies over the years, including recently: Division of Biology, College of Arts and Sciences, Offices of Provost and Chancellor, Departments of Anthropology, Psychology, Biochemistry and Cellular and Molecular Biology, Earth and Planetary Sciences, Microbiology, Physics and Astronomy; HainesMorris Fund, College of Education, Health, and Human Sciences, Frank H. McClung Museum, and Graduate School of Genome Science and Technology at UTK; Oak Ridge National Laboratory; and Tennessee Valley Unitarian Universalist Church. Helpful comments on this manuscript were provided by our organization's founder Massimo Pigliucci and former president Marc Cadotte.

\section{References}

American Association for the Advancement of Science. Press RoomEvolution on the frontline. Washington, D.C.: AAAS; 2006. http://www.aaas.org/news/press_room/evolution.

Anonymous. The Darwin Celebration, Am Museum J 1909;9:3.

Blount County Board of Education. Official minutes of the Blount County Board of Education. Blount County: Blount County Board of Education; 2005. www.blountk12.org/BdofEd/BdMinutes/0405/january\%2013\%202005.doc.
University of Tennessee. Darwin Day at UTK. Knoxville: UTK; 2008. http://eeb.bio.utk.edu/darwin.

Darwin Festival (SM). Darwin Festival History. 2008. http://w3. salemstate.edu/. Accessed Jan 2008.

DeWolf DK, Meyer SC, DeForrest ME. Teaching the controversy: Darwinism and the public school curriculum. Richardson: Foundation for Thought and Ethics; 1999.

Fail J. Teach evolution early. Bioscience 2006;56:877.

Matzke N, Gross P. Analyzing critical analysis: The fallback antievolutionists strategy. In: Scott EC, Branch G, editors. Not in Our Classrooms: Why Intelligent Design is Wrong for Our Schools. Boston: Beacon; 2006. p. 28-56.

Miller JD, Scott EC, Okamoto S. Public acceptance of evolution. Science 2006;313:765-6.

National Academies. Science, Evolution, and Creationism. Washington, D.C.: National Academies; 2008. http://www.nap.edu/sec.

Schueler FW. Darwin Day Phylum Feast: History. 2008. http:// pinicola.ca/darwind2.htm. Accessed Jan 2008.

Slevin P. Battle on teaching evolution sharpens. Washington Post Mar 14 2005:A01.

Stout D. Frist urges two teachings on life origin. New York Times Aug 20 2005:A10.

The Clergy Letter Project. Clergy letter. 2006. http://www.uwosh.edu/ colleges/cols/rel_evol_sun.htm. Accessed Jan 2008.

The Humanist Community. Darwin Day. 2008. http://humanists.org/ dday.htm. Accessed Jan 2008.

West JG. Darwin Day In America: How Our Politics and Culture Have Been Dehumanized in the Name of Science. Wilmington: ISI Books; 2007. 